\title{
Examining Ethnocentrism, Emotionalization, and Life Syllabus in Foreign Language Achievement
}

\author{
Golshan Shakeebaee \\ M.A., Language Education, Ferdowsi University of Mashhad, Iran,
} golshan.shakeebaee@mail.um.ac.ir

\section{Reza Pishghadam}

Prof., corresponding author, Language Education, Ferdowsi University of Mashhad, Iran,pishghadam@um.ac.ir

\section{Gholam Hassan Khajavy}

Asst. Prof., Language Education, University of Bojnord, Bojnord, Iran, hasan.khajavi@gmail.com

Given the importance of ethnocentrism in social interactions and its influence on language learning and teaching, the present study intends to explore the possible relationships between using life syllabus and emotionalization on ethnocentric views using the foreign language achievement (FLA) scores. To this end, 273 Iranian English learners from different language institutes completed the scales. Structural equation modelling (SEM) was utilized to examine the possible interactions. The findings indicated that while exvolvement, as a part of emotionalization, leads to higher FLA scores, involvement shows the opposite results. In addition, the results revealed that the language aspect of the life syllabus leads to higher FLA scores, and ethnocentrism was found to be less related to FLA. In the end, the results were discussed and some suggestions were made to help policy makers and materials developers modify the existing syllabuses.

Keywords: emotionalization, ethnocentrism, life syllabus, foreign language achievement score, foreign language, language achievement

\section{INTRODUCTION}

Ethnocentrism is held to be an integral part of human beings' society (Njoroge \& Kirori, 2014). Coined by Sumner (1906) in the early twentieth century, the term can be defined as a phenomenon in which each person's group is in the center while other cultures revolve around it. He further claims that "each group thinks its own folkways the only right ones, and if it observes that other groups have other folkways, these excite its

Citation: Shakeebaee, G., Pishghadam, R., \& Khajavy, G. H. (2017). Examining Ethnocentrism, Emotionalization, and Life Syllabus in Foreign Language Achievement. International Journal of Instruction, 10(4), 343-360. https://doi.org/10.12973/iji.2017.10420a 
scorn" (p.13). Ethnocentrism is considered to be manifested in various social interactions (Perreault \& Bourhis, 1999), one of which is learning a foreign language. In fact, it plays a major role in language education, and a large number of studies over the years (e.g., Adorno, Frenkel-Brunswik, Levinson, \& Sanford, 1950; Hosseini Fatemi, Khajavy, \& Choi, 2016; Jajobovits, 1968; Putnam, 2011) endorse its importance. Such studies have provided empirical supports for the notion that knowing a foreign language may reduce ethnic-related issues such as social distance, stereotyping, and ethnic hostility. Relatedly, Lett (1976) maintained that increasing cross-cultural understanding might decrease ethnocentrism. Thus, learning a foreign language may lead to a better understanding of cross-cultural differences. She further continued that understanding cross-cultural differences can be imparted to students by teachers and their experiences or good teaching materials.

In this regard, it can be claimed that syllabus, "a framework for selecting and designing teaching materials" (Chanie, 2013, p. 69), can be helpful in shaping cross-cultural awareness (Knutson, 2006). A syllabus can be defined as a statement of what is to be learned (Hutchinson \& Waters, 1987), including some features such as socio-cultural and communicative activities, flexibility, and coherence (Brumfit, 1984). Syllabuses can be organized in different ways, such as product-oriented or process-oriented (Nunan, 1988). Given the dominance of language issues in these syllabuses (Pishghadam, Zabihi, $\&$ Shayesteh, 2015) and the points raised by Freire (1994) on participatory education, Pishghadam and Zabihi (2012) introduced the notion of life syllabus. They are of the view that more importance is required to be attached to life rather than language (Pishghadam, Zabihi, \& Ghadiri, 2014). In fact, this notion is closely related to English for life purpose (ELP), which not only does pay attention to learners' levels of anxiety and depression, but also enhances the learners' emotional and motivational activities (Pishghadam, Zabihi, \& Kermanshahi, 2012).

The traces of life syllabus can be found in a newly developed concept proposed by Pishghadam, Tabatabaeyan, and Navari (2013), named emotioncy, which is a combination of emotions and frequency of senses. Emotioncy, in its simplest definition, deals with the emo-sensory aspect of learning (Pishghadam Adamson, \& Shayesteh, 2013; Pishghadam, Shayesteh, \& Rahmani, 2016), which can be inextricably interwoven to real life experiences. In fact, emotionalization, which refers to increasing the level of emotioncy by teachers, seems to be intertwined with the life syllabus and ethnocentrism, affecting language learning. With that in mind, we first validate the modified version of ethnocentrism scale designed by Neuliep and McCroskey (1997) to fit our context, and then determine whether there are any significant relationships between ethnocentrism, emotioncy, and life syllabus with regard to foreign language achievement (FLA) scores.

\section{LITERATURE REVIEW}

\section{Ethnocentrism}

Each person learns various ways of living from the particular culture that $\mathrm{s} / \mathrm{he}$ is born into it. When dealing with people from other cultures, one might find him/herself working with different mindsets and norms, which might seem unusual, and even 
sometimes odd. This might lead to negative intercultural experiences, which may consequently cause people to make judgments about cultural groups (Wintergerst \& McVeigh, 2011). Such negative perceptions of difference might lead to ethnocentrism, in which the new culture is not only odd, but also inferior and even wrong (Atingdui, 2011). In other words, one's own ethnic group is superior to other ethnic groups (Hooghe, 2008). Neuliep, Chaudoir, and McCroskey (2001) claim that ethnocentrism is more common in cosmopolitan societies and causes gaps between in-group and outgroup communities. They also believe that identifying these societies can be beneficial in terms of controlling and decreasing disagreements and conflicts. Ethnocentrism affects the way individuals see different cultures and influences their interactions (Hosseini Fatemi et al., 2016). Relatedly, studies (e.g., Cadd, 1994; Yu \& Chia-Fang, 2008) have shown that studying another language familiarizes individuals with the target language's norms and cultures largely, that might reduce the levels of ethnocentrism. In another relevant article, Putnam (2011) indicates that knowledge of a second or foreign language plays a significant role in the learners' intercultural misunderstandings and the levels of ethnocentrism. She also believes when the connection between language and culture is acknowledged, "language students will find their eyes and minds opened to a new world of perspectives, behaviour, and culture" (p. 55). Similarly, Cadd (1994) claims that studying another language may reduce the degree of ethnocentrism, because "teachers of foreign languages emphasize the cross-cultural awareness, openmindedness, and liberation of mind" (p. 144).

\section{Life Syllabus}

Various needs of learners and emergence of different approaches and methods have led syllabus design to undergo numerous changes during the time. Despite the vast body of research on syllabus design, there is no unanimous definition for such a term. In one definition, Matejka and Kurke (1994) considered syllabus as a contract, a plan, a communicative device, and a cognitive map for teachers, and they have concluded that it is important to have it designed with caution. From this perspective, in order to design a syllabus, information from and about learners should be collected, and needs analysis should be conducted to get a more comprehensive understanding (Nunan, 1988).

The unprecedented changes regarding syllabus design have also led to various classifications for syllabus. In one case for example, Nunan (1988) classifies syllabuses as product-oriented and process-oriented. The former term, with its traditional orientation and its roots in linguistics, is applied when the syllabus's objective for a learner is to know a subject as a result of instruction. The latter term refers to a series of actions leading to an end. Here, learners focus on learning experiences. Based on such classification, many studies (e.g., Candlin, 1984) have examined syllabus from different points of view, leading to the conclusion that the content of the class should not be decided apriori and it should occur in the very heat of the moments of the classroom. The other related issue regarding syllabus can be found in the notion that such syllabuses mostly pay attention to the pedagogical aspects of education. In this sense, Pishghadam et al. (2015) believe that promoting life qualities in education is an important factor. They believe that life-related factors such as social relations, human 
rights, and emotional/physical abilities should be taken into account and boosted in educational contexts. Therefore, life syllabus, with its roots in the notion of applied ELT, was proposed by Pishghadam and Zabihi (2012), aiming to go beyond the usual linguistic syllabuses which are normally used in ELT and to present a syllabus that takes life issues into consideration.

Pishghadam (2011) is of the view that learners are expected to learn about life via learning English. Therefore, ELT directs its focus from language-only classes to language-and-life classes. Thus, a language learning classroom must be a class that life issues are noted and taken into consideration (Pishghadam et al., 2015). Moreover, teachers should utilize unique features of classes to improve critical abilities, creativity, social intelligence, emotional intelligence, etc., and to teach a language (Pishghadam, 2011). It seems learning life skills is a practice that deals with individuals' life challenges such as stress, depression, and burnout prior to their educational needs.

\section{Emotionalization}

Substantiating the importance of emotions in language education, and by using Greenspan's (1992) developmental individual-differences relationship-based (DIR) model for first language acquisition, Pishghadam, Adamson, et al. (2013) cast a fresh eye on second language education, and introduced emotion-based language instruction (EBLI). The notion of EBLI sheds light on the emotions that learners transfer from their first language to their second language, which is based on the concepts of emotioncy, emotionalization, and inter-emotionality (Pishghadam, Adamson, et al., 2013). In this regard, emotionalization can be defined as "establishing emotions for L2 lexical items" (Pishghadam \& Shayesteh, 2017, p. 5). To further develop the concept, Pishghadam (2015) divided emotioncy into various kinds and types (see Table 1 for the conceptual definitions).

Table 1

Emotioncy Categorization

\begin{tabular}{|c|c|c|}
\hline \multicolumn{2}{|l|}{ Emotioncy } & \multirow[b]{2}{*}{ Experience } \\
\hline Types & Kinds & \\
\hline Avolvement & Null & $\begin{array}{l}\text { When an individual has not heard about, seen, or experienced an } \\
\text { object or a concept. }\end{array}$ \\
\hline \multirow[t]{3}{*}{ Exvolvement } & Audio & When an individual has merely heard of a word/concept \\
\hline & Visual & When an individual has both heard about and seen the item. \\
\hline & Kinesthetic & $\begin{array}{l}\text { When an individual has touched, worked, or played with the real } \\
\text { object. }\end{array}$ \\
\hline \multirow[t]{2}{*}{ Involvement } & Inner & When an individual has directly experienced the word/ concept. \\
\hline & Arch & $\begin{array}{l}\text { When an individual has done research to get additional } \\
\text { information. }\end{array}$ \\
\hline
\end{tabular}

Note. Adapted from "Conceptualizing Sensory Relativism in Light of Emotioncy: A Movement Beyond Linguistic Relativism," by R. Pishghadam, H. Jajarmi, and S. Shayesteh, 2016, International Journal of Society, Culture and Language, p.4. 
In a related article, Pishghadam, Jajarmi, and Shayesteh (2016) introduced the theoretical basis for this newly developed concept through sensory relativism, as opposed to cognitive and social constructivism introduced many years ago by Piaget (1954) and Vygotsky (1978), respectively. They presented the continuum of emotioncy (Figure 1) as the following.

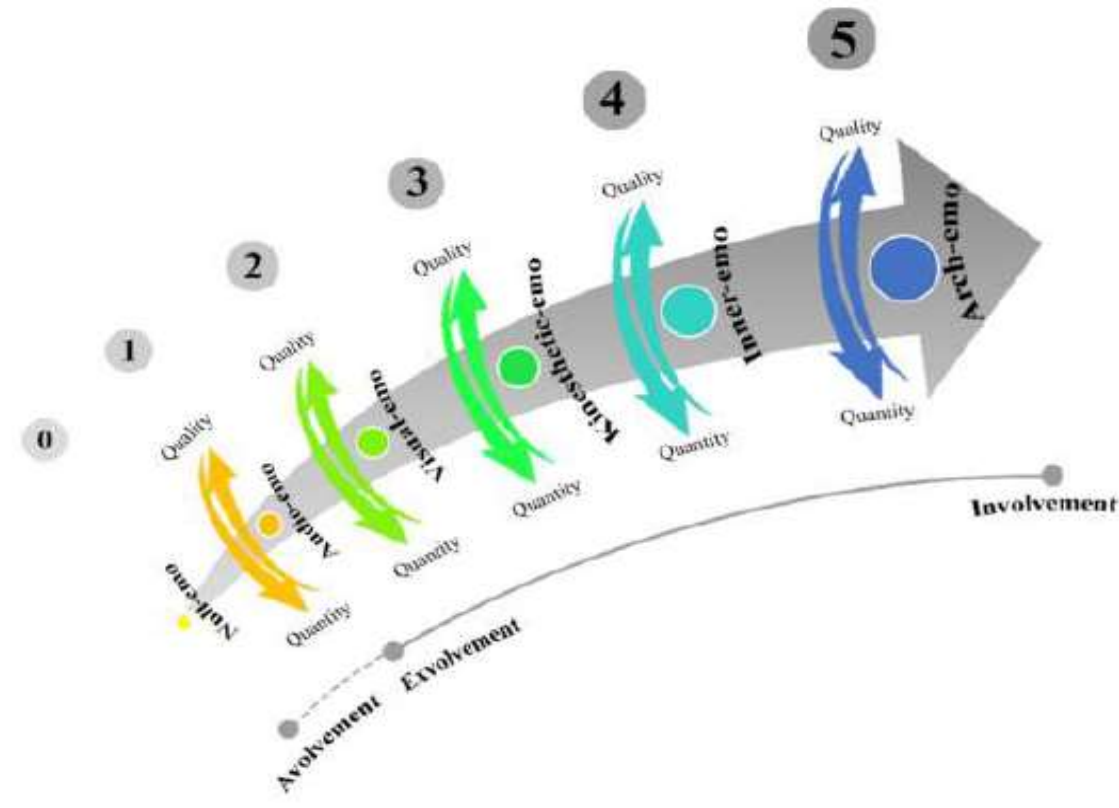

Figure 1

Emotioncy levels. Adapted from "Emotioncy, Extroversion, and Anxiety in Willingness to Communicate in English," by R. Pishghadam, 2016, the $5^{\text {th }}$ International Conference on Language, Education, and Innovation. p. 2

As illustrated in Figure 1, with increasing the level of emotioncy, the level of comprehension seems to improve. In other words, "the lower-level emotioncy (auditory, visual, \& kinesthetic) leads to exvolvement since they engage students' emotions from outside, while the upper-level emotioncy (inner \& arch) results in involvement as they engage learners from inside" (Pishghadam, Baghaei, \& Seyednozadi, 2017, p. 130). In addition, avolvement indicates null emotioncy, which means the learner has no idea about that specific content (Pishghadam, 2016).

Pedagogically speaking, exvolvement can be related to linguistic and involvement to non-linguistic aspects of the class. To be more specific, involvement can be linked to life syllabus, since the more important a concept is for a person, the deeper s/he gets involved in that given concept. Therefore, it seems involvement leans toward life-related issues because involvement is more related to actual and real-life experiences. 


\section{PURPOSE OF THE STUDY}

As already mentioned, the major objective of the study was to examine the relationships between emotionalization, life syllabus, ethnocentrism, and FLA scores. To this end, we needed valid instruments to measure the learners' attitudes. The scales for life syllabus (original scale, Bahari, 2014; modified version, Shakeebaee, 2016) and emotionalization (Pishghadam, Shayesteh, et al., 2016) were available. However, the developed scale for measuring ethnocentrism (Neuliep \& McCroskey, 1997) did not seem to serve the purpose of this study, for it was a general scale not related to academic situations. Therefore, the present study intends to answer the following questions:

Q1. Does the modified version of ethnocentrism scale meet psychometric properties?

Q2. Are there any significant relationships between ethnocentrism, emotioncy, and life syllabus with respect to FLA scores?

\section{METHOD}

\section{Participants}

The sample consisted of 273 adult participants (100 males \& 173 females) aged 18 to 48 $(M=26.01, S D=6.42)$ with Persian as their first language. They were English learners of pre-intermediate to advanced proficiency levels who were studying at six English language institutes in Mashhad, Iran. The sample selection was based on convenience sampling, and the participation was voluntary.

\section{Instruments}

\section{Ethnocentrism Scale}

To evaluate the language learners' ethnocentric attitudes, a modified version of ethnocentrism scale, which was originally designed by Neuliep and McCroskey (1997), was used. The original scale has 22 items measured on a five-point Likert-type scale ranging from 1 (strongly disagree) to 5 (strongly agree). The modified version has the same number of items, but it has been changed to a six-point Likert-type scale ranging from 1 (strongly disagree) to 6 (strongly agree) to avoid neutrality. The structure and the concept of the questions have not changed, whereas it has been modified to reflect participation in an English class (Appendix 1).

\section{Emotionalization Scale}

To assess the level of the established emotioncy by teachers through students' evaluation, emotionalization scale, which is a 23-item scale (Pishghadam, Rahmani, et al., 2016) measured on a five-point Likert-type scale ranging from 1 (never) to 5 (always), was used (Appendix 2). In the original study, the reliability using Cronbach's alpha was 0.82 . In addition, the scale was validated and the results are presented in the following sections.

\section{Life Syllabus Scale}

To assess the teachers' use of life syllabus through students' evaluation, a 29-item scale (Bahari, 2014; Shakeebaee, 2016), measured by a five-point Likert-type scale ranging 
from 1 (strongly disagree) to 5 (strongly agree), was used (Appendix 3). In the original study, the reliability using Cronbach's alpha was 0.88 , and the scale was validated through Rasch analysis.

\section{Procedure}

Before data collection and based on the related literature, the ethnocentrism scale (Neuliep \& McCroskey, 1997) was modified to reflect the class attendance and ethnocentric views. Then, the questions were translated into the learners' mother tongue (Persian). The translated scale was given to two Iranian instructors with a good command of English, and their ideas were considered. The scale was then piloted, and the opinions of the participants in the pilot group were considered.

The data collection was conducted at six different language institutes in Mashhad, a city in the northeast of Iran. The ethnocentrism scale along with emotionalization and life syllabus scales was given to the English learners. To facilitate the process of gathering the data and to make sure that all of the participants would understand the intended meanings, the scales along with the instructions were presented in Persian (the participants' mother tongue). Overall, it took around 15-20 minutes for the participants to complete the scales. Before the administration stage, permission was obtained from the authorities of the institutes. Furthermore, the students were assured that their answers would remain anonymous and their participation was not obligatory. Finally, structural equation modelling (SEM) was used to analyze the data.

\section{FINDINGS}

\section{Descriptive Statistics}

Before statistical analyses, data screening was performed using IBM SPSS 22. Normal distribution was also checked using skewness and kurtosis indices. Table 2 demonstrates the descriptive results of the scales.

Table 2

Descriptive Statistics

\begin{tabular}{llllccc}
\hline Scales & N of items & $M$ & $S D$ & Cronbach's alpha & Skewness & Kurtosis \\
\cline { 2 - 7 } Emotionalization & 23 & 66.18 & 20.93 & .96 & -.006 & -.05 \\
Ethnocentrism & $21 *$ & 72.38 & 7.49 & .91 & .41 & .03 \\
Life syllabus & 29 & 79.35 & 14.59 & .89 & .62 & -.39 \\
\hline
\end{tabular}

Note. $*$ The original scale includes 22 items, but after conducting exploratory factor analysis (EFA), question number 12 was not loaded in any of the components; therefore, it was omitted.

\section{Confirmatory Factor Analysis}

\section{Ethnocentrism Scale}

One part of this study aims at substantiating the construct validity of the ethnocentrism scale. First, exploratory factor analysis (EFA) was used, and the principle component analysis revealed the presence of three components (namely xenophobia, chauvinism, \& respect) with eigenvalues exceeding 1 . CFA was then used to see if these components 
can be confirmed. The association between each component can be seen in Figure 2 and Table 3.

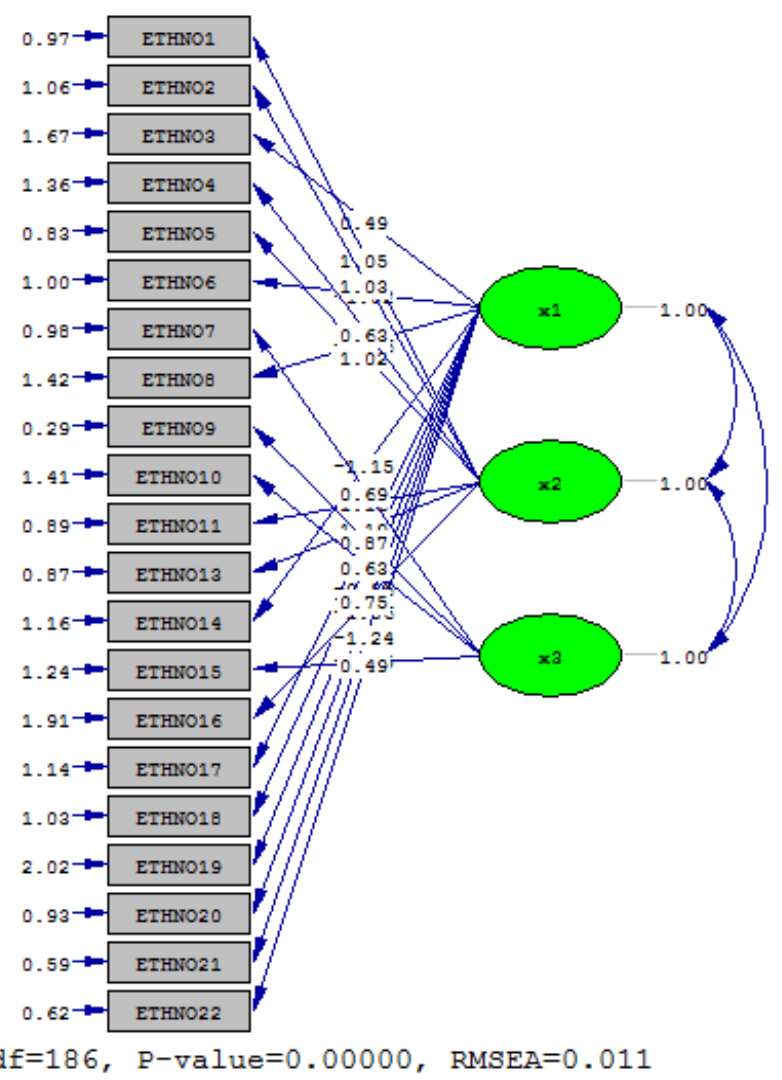

Chi-Square $=507.69, \mathrm{df}=186, \mathrm{P}$-value $=0.00000, \mathrm{RMSEA}=0.011$

Figure 2

CFA model for ethnocentrism scale

Generally, if any of mentioned indices are above .90 , it can be concluded that the model fits (Kunnan, 1998). According to Table 3, the CFA confirmed the structure of ethnocentrism scale.

Table 3

Model-Fit Indices for Ethnocentrism Scale

\begin{tabular}{llccccc}
\hline Indices & $\chi 2 / d f$ & RMSEA & NFI & GFI & IFI & CFI \\
\hline Acceptable fit & 2.73 & 1.0 & .93 & .91 & .92 & .93 \\
\hline
\end{tabular}

\section{Interactions of the Scales}

Similar to the ethnocentrism scale, model fit indices were examined for this scale. Based on the obtained results (Table 4), the model fits the data adequately and confirms the structure of the scale. 
Table 4

Model-Fit Indices

\begin{tabular}{llllll}
\hline$\chi^{2} / d f$ & RMSEA & NFI & GFI & IFI & CFI \\
\hline 2.89 & 0.07 & 0.92 & 0.93 & 0.91 & 0.92 \\
\hline
\end{tabular}

As it can be seen in Figure 3, there is no significant relationship between ethnocentrism and FLA scores. However, the path from involvement to score is negative and significant $(\beta=-.54, \mathrm{p}<.05)$. Besides, there is a positive and significant relationship between exvolvement and score $(\beta=.70, p<0.05)$. Another significantly negative path was seen between life syllabus and score $(\beta=-.20, \mathrm{p}<0.05)$.

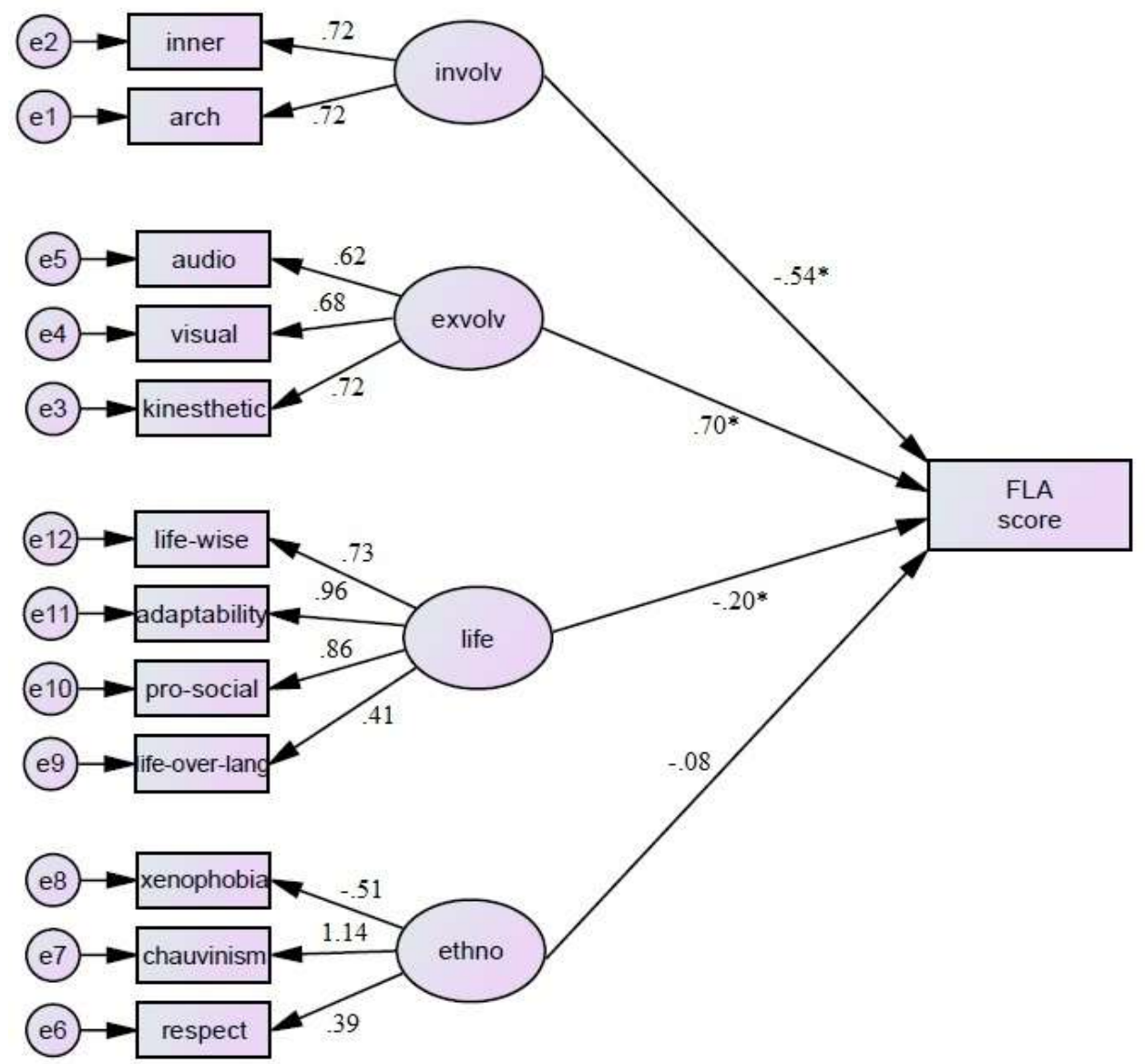

Figure 3

The schematic representation of the relationships among life syllabus, emotionalization, and ethnocentrism regarding FLA score.

Note. All paths except ethnocentrism to score are significant at least at $p<.05$. 


\section{DISCUSSION}

As already mentioned, the major objectives of the present study were to validate the modified version of ethnocentrism scale designed by Neuliep and McCroskey (1997), and to determine if there are any significant relationships between ethnocentrism, emotioncy, and life syllabus with regard to FLA scores.

As the outcomes of the study revealed, there is a negative relationship between involvement, as a component of emotioncy, and FLA scores. This set of finding is in line with Pishghadam, Seyednozadi, and Zabetipour's (in press) study on emotionalization and life syllabus, in which they have found that exvolvement leads to higher achievement scores, while involvement leads to lower scores. Apparently, involvement subscales (i.e., inner $\&$ arch) do not necessarily lead to a higher achievement score. Pishghadam, Shayesteh, et al. (2016) claim that in the emotioncy hierarchy, inner and arch include carrying out surveys, finding online friends, and so forth. It is speculated that while doing these activities may increase the level of emotioncy toward a specific linguistic concept, absence of some facilities, including online access to web sites, lack of time, and reluctance on the side of students may lead to this negative relationship. It seems that conducting such activities digress students and teachers' attention from covering the book, which is the focus of the class.

Moreover, exvolvement subscales (i.e., audio, visual, \& kinaesthetic), and their related activities are frequently used by the teachers. Therefore, they may affect the obtained scores. In fact, the positive relationship between exvolvement and the score endorses the popularity of exvolvement-related activities over the involvement-related ones. Another reason might be the fact that the involvement-related activities are not as available as those of exvolvement ones. In other words, every teacher has access to books, pictures, and audio files, but due to many reasons such as limited sources of time and money, not everyone can run involvement-related activities. It is worth mentioning that such activities may affect teachers' success and may lead to a more vivid class, but does not necessarily guarantee students' better performance. Moreover, many learners are reluctant to get involved in involvement-related activities.

With respect to the negative relationship between life syllabus and FLA scores, it should be mentioned that the test used to obtain the FLA scores was based on a productoriented syllabus. As life syllabus is not a product-oriented syllabus, it may not lead to a better FLA score in a test that intends to measure the final products, and the obtained negative relationship between life syllabus and FLA scores can be justified in this vein. In other words, product-oriented syllabuses are those which merely aim at acquiring knowledge and skills (Nunan, 1988); therefore, as the exam was only based on the book, it only included linguistic aspects.

Regarding ethnocentrism, no significant relationship was found between ethnocentric views and FLA scores. This finding may indicate that ethnocentrism does not affect language performance. One possible line of justification for this finding is that English is a foreign language in Iran and therefore, is not spoken outside the classroom. In fact, little contact with real English may be a factor in supporting ethnocentric views. 
Moreover, since Iranians are mostly religious, they may stick hard to their beliefs and resist any changes in ethnocentrism.

\section{CONCLUSION AND IMPLICATIONS}

Results of the analysis indicated that more involvement and more use of life syllabus might lead to higher scores. It is suggested that teachers talk to learners about such activities to prevent misunderstandings. In other words, it is suggested that teachers state the rationale behind doing extracurricular activities to motivate learners. This claim is in line with Dörnyei's (1994) learning-specific motivational components, in which he considers learning tasks as a course-specific motivational component. He further states that relevance is the extent that a learner may feel the instruction is related to personal needs. Therefore, it can be concluded that if learners know about the logic behind involvement-related tasks (i.e., conducting interviews, doing research on topics, etc.), they do not consider them as laborious and time-consuming. Furthermore, as life syllabus merges language learning into life-related issues (Pishghadam \& Zabihi, 2012), teachers should take advantages of the schizophrenic nature of English classes to help learners create or keep identities (Pishghadam, 2011). Teachers can also make students alert about the pros of foreign cultures and nativize them to enrich the home culture and prevent cultural derichment (Pishghadam et al., 2015), and this cannot be achieved unless some modifications are made in the current syllabuses and methods.

All in all, the present study was based on statistical methods such as SEM and CFA, which intended to explore the roles of life syllabus, emotionalization, and ethnocentric views of EFL learners in Iran. Like all studies, the present study is certainly not without limitations. One of the limitations is related to the small sample size, which restricts the generalization of the obtained findings. As the ethnocentric view and score did not have a significant relationship, further studies are needed to investigate the possible reasons. Since the age of students seems to play a role in this study, it is suggested that further similar studies be carried out to focus on this important variable. Moreover, although the ethnocentrism scale measured the level of ethnocentrism after attending English classes, it is advised to design a study in which the level of ethnocentrism is measured before and after class attendance to get to more reliable results. Furthermore, the present study did not show which part of life syllabus and emotionalization scales are specifically related to ethnocentric views. In this regard, further studies need to be conducted to determine which aspects of the scales mentioned above lead to ethnocentric views. It is advised to conduct a qualitative phase such as interviews and think-aloud procedures to obtain more comprehensive and generalizable results. 


\section{REFERENCES}

Adorno, T. W., Frenkel-Brunswik, E., Levinson, D. J., \& Sanford, R. N. (1950). The authoritarian personality. Retrieved from http://www.ajcarchives.org/main.php?GroupingId=6490

Atingdui, N. (2011). Ethnocentrism. In S. Goldstein \& J. A. Naglieri (Ed), Encyclopedia of child behavior and development (pp. 607-608). London: Springer.

Bahari, N. (2014). Constructing and validating a scale of educational English language teacher (Unpublished master thesis). Ferdowsi University of Mashhad, Iran.

Brumfit, G. J. (1984). General English syllabus design. Oxford: Pergamon Press.

Cadd, M. (1994). An attempt to reduce ethnocentrism in the foreign language classroom. Foreign Language Annals, 27(2), 143-160.

Chanie, B. S. (2013). Conceptions about language syllabus and textbook-based instructions: TEFL graduate students in focus. Online Journal of Education Research, 2(4), 66-71.

Dörnyei, Z. (1994). Motivation and motivating in the foreign language classroom. The Modern Language Journal, 78(3), 273-284.

Freire, P. (1994). Pedagogy of the oppressed. London: Continuum.

Greenspan, S. I. (1992). Infancy and early childhood: The practice of clinical assessment and intervention with emotional and developmental challenges. Madison, CT: International Universities Press.

Hooghe, M. (2008). Ethnocentrism. In W. A. Darity (Ed.), International encyclopedia of the social sciences (pp. 11-12). Detroit: Gale.

Hosseini Fatemi, A., Khajavy, G. H., \& Choi, C. W. (2016). Testing a model of intercultural willingness to communicate based on ethnocentrism, ambiguity tolerance and sensation seeking: The role of learning English in Iran. Journal of Intercultural Communication Research, 45(4), 1-15.

Hutchison T., \& Waters A. (1987). English for specific purposes. Cambridge: Cambridge University Press.

Jakobovits, L. A. (1968). Dimensionality of compound-coordinate bilingualism. Language Learning, 18(3), 29-56.

Knutson, E. (2006). Cross-cultural awareness for second/foreign language learners. Canadian Modern Language Review, 62(4), 591-610.

Kunnan, A. J. (1998). An introduction to structural equation modelling for language assessment research. Language Testing, 15(3), 295-332. 
Lett, J. A. (1976). The relationship of foreign language study to close-mindedness and ethnocentrism among selected secondary school students (Doctoral dissertation). Retrieved from https://etd.ohiolink.edu/rws_etd/document/get/osu1345748959/inline

Matejka, K., \& Kurke, L. B. (1994). Designing a great syllabus. College Teaching, 42(3), 115-117.

Neuliep, J. W., \& McCroskey, J. C. (1997). The development of intercultural and interethnic communication apprehension scales. Communication Research Reports, 14(2), 385-398.

Neuliep, J. W., Chaudoir, M., \& McCroskey, J. C. (2001). A cross-cultural comparison of ethnocentrism among Japanese and United States college students. Communication Research Reports, 18(2), 137-146.

Njoroge, M. W., \& Kirori, G. N. (2014). Ethnocentrism: Significance and effects on Kenyan society. African Journal of Political Science and International Relations, 8(9), 356-367.

Nunan, D. (1988). Syllabus design. Oxford: Oxford University Press.

Perreault, S., \& Bourhis, R. Y. (1999). Ethnocentrism, social identification, and discrimination. Personality and Social Psychology Bulletin, 25(1), 92-103.

Piaget, J. (1954). The construction of reality in the child. New York: Basic Books.

Pishghadam, R. (2011). Introducing applied ELT as a new approach in second/ foreign language studies. Iranian EFL Journal, 7(6), 8-14.

Pishghadam, R. (2015, October). Emotioncy in language education: From exvolvement to involvement. Paper presented at the $2^{\text {nd }}$ Conference on Interdisciplinary Approaches on Language Teaching, Literature, and Translation Studies. Ferdowsi University of Mashhad, Iran.

Pishghadam, R. (2016, May). Emotioncy, extroversion, and anxiety in willingness to communicate in English. Paper presented at the $5^{\text {th }}$ International Conference on Language, Education, and Innovation, London, England.

Pishghadam, R., \& Shayesteh, S. (2017). The consolidation of life issues and language teaching on the life-language model of emotioncy. Humanising Language Teaching, 19(1), 1-14.

Pishghadam, R., \& Zabihi, R. (2012). Life syllabus: A new research agenda in English language teaching. TESOL Arabia Perspectives, 19(1), 23-27.

Pishghadam, R., Adamson, B., \& Shayesteh, S. (2013). Emotion-based language instruction (EBLI) as a new perspective in bilingual education. Multilingual Education, $3(9), 1-16$. 
Pishghadam, R., Baghaei, P., \& Seyednozadi, Z. (2017). Introducing emotioncy as a potential source of test bias: A mixed Rasch modeling study, International Journal of Testing, 17(2), 127-140.

Pishghadam, R., Jajarmi, H., \& Shayesteh, S. (2016). Conceptualizing sensory relativism in light of emotioncy: A movement beyond linguistic relativism. International Journal of Society, Culture \& Language, 4(2), 11-21.

Pishghadam, R., Seyednozadi, Z., \& Zabetipour, M. (in press). Examining teacher credibility and academic achievement in light of emotionalization and life syllabus. International Journal of Pedagogies and Learning.

Pishghadam, R., Shayesteh, S., \& Rahmani, S. (2016). Contextualizationemotionalization interface: A case of teacher effectiveness. International and Multidisciplinary Journal of Social Sciences, 5(6), 1-22.

Pishghadam, R., Tabatabaeyan, M. S., \& Navari, S. (2013). A critical and practical analysis of first language acquisition theories: The origin and development. Mashhad, Iran: Ferdowsi University of Mashhad.

Pishghadam, R., Zabihi, R., \& Ghadiri, M. (2014). Teachers' feedback on EFL students' writings: A linguistic or life syllabus perspective. Humanising Language Teaching, 16(1), 1-18.

Pishghadam, R., Zabihi, R., \& Kermanshahi, P. (2012). Educational language teaching: A new movement beyond reflective/critical teaching. Life Science Journal, 9(1), 892899.

Pishghadam, R., Zabihi, R., \& Shayesteh, S. (2015). Applied ELT: A movement beyond applied linguistics. Iran: Khate Sefid Publications.

Putman, W. (2011). A sociocultural approach to ESL for adult learners (master's thesis). Retrieved from http://digitalcommons.usu.edu/gradreports/12

Shakeebaee, G. (2016). Life syllabus and emotionalization in molding ethnocentric views: A case of Iranian EFL learners (Unpublished master's thesis). Ferdowsi University of Mashhad, Mashhad, Iran.

Sumner, W. G. (1906). Folkways: A study of the sociological importance of usage. Boston, MA: Ginn.

Vygotsky, L. S. (1978). Mind in society: The development of higher psychological processes. Cambridge: Harvard University Press.

Wintergerst, A. C., \& McVeigh, J. (2011). Tips for teaching culture: Practical approaches to intercultural communication. NY: Pearson.

Yu, L., \& Chia-Fang, H. (2008). Willingness to communicate in intercultural interactions between Chinese and Americans. Journal of Intercultural Communication Research, 37(2), 75-88. 


\section{Appendices}

\section{Appendix 1}

\section{Sample items of the ethnocentrism scale}

\begin{tabular}{|l|l|l|l|l|l|l|}
\hline & $\begin{array}{c}\text { Strongly } \\
\text { agree }\end{array}$ & Agree & $\begin{array}{c}\text { Somehow } \\
\text { agree }\end{array}$ & $\begin{array}{c}\text { Somehow } \\
\text { disagree }\end{array}$ & Disagree & $\begin{array}{c}\text { Strongly } \\
\text { disagree }\end{array}$ \\
\hline $\begin{array}{l}\text { When I am in the class, I feel my } \\
\text { culture is better than other cultures. }\end{array}$ & & & & & & \\
\hline $\begin{array}{l}\text { By attending English classes, I feel I } \\
\text { cannot trust people from other } \\
\text { races. }\end{array}$ & & & & & & \\
\hline $\begin{array}{l}\text { By attending class, I have } \\
\text { understood that my own race does } \\
\text { not know what is good for them }\end{array}$ & & & & & & \\
\hline
\end{tabular}

\section{Appendix 2}

\section{Sample Items of the emotionalization scale}

\begin{tabular}{|l|l|l|l|l|l|}
\hline $\begin{array}{l}\text { Audio: } \\
\text { My teacher makes us listen to the shared experiences about } \\
\text { different concepts (in pairs or in groups) }\end{array}$ & Never & Rarely & Sometimes & Often & Always \\
\hline $\begin{array}{l}\text { Visual: } \\
\text { My teacher does not use pictures to elaborate on new concepts. }\end{array}$ & & & & & \\
\hline $\begin{array}{l}\text { Kinesthetic: } \\
\text { My teacher makes us play games to deepen our understanding of } \\
\text { some concepts. }\end{array}$ & & & & & \\
\hline $\begin{array}{l}\text { Inner: } \\
\text { My teacher makes us simulate (copy) certain situations. }\end{array}$ & & & & & \\
\hline $\begin{array}{l}\text { Arch: } \\
\text { My teacher wants us to do some research on certain new } \\
\text { concepts and present in the class. }\end{array}$ & & & & & \\
\hline
\end{tabular}

\section{Appendix 3}

\section{Sample items of the life syllabus scale}

\begin{tabular}{|l|l|l|l|l|l|}
\hline & Strongly agree & Agree & Neutral & Disagree & Strongly disagree \\
\hline My teacher tries to nourish critical thinking. & & & & & \\
\hline My teacher does not care about ethical issues. & & & & & \\
\hline My teacher puts emphasis on dialogue & & & & & \\
\hline
\end{tabular}




\section{Turkish Abstract \\ Etnosentrism, Duygusallaştırma ve Hayat Boyu Öğrenme Programının Yabancı Dil Başarısında İncelenmesi}

Toplumsal etkileşimlerde etnosentrizmin önemi ve bunun dil öğrenme ve öğretim üzerindeki etkisi göz önüne alındığında, bu çalışma hayat bilgisi ve etnosentrik görüşlerin duygusallaştırılması arasındaki olası ilişkileri yabancı dil başarı (FLA) skorlarını kullanarak araştırmayı amaçlamaktadır. Olası etkileşimleri incelemek iç̧in Yapısal Eşitlik Modellenmesi (SEM) kullanılmıştır. Bulgular, duygusallaştırmanın bir parçası olarak katılımın daha yüksek FLA puanlarına yol açmasına karșın ters sonuçlara işaret ettiğini göstermiștir. Buna ek olarak, sonuçlar, yaşam sürecinin dil boyutunun daha yüksek FLA puanlarına yol açtı̆̆ını ve etnosentrizmanın FLA ile daha az ilişskili olduğu ortaya çıkarmıştır.

Anahtar Kelimeler: duygusallaştırma, etnosentrizm, yaşam süreci, yabancı dil başarı puanı, yabancı dil, dil başarısı

\section{French Abstract}

En examinant Ethnocentrisme, Emotionalization et Programme de Vie dans Accomplissement de Langue étrangère

Étant donné l'importance d'ethnocentrisme dans des interactions sociales et son influence sur l'apprentissage des langues et l'enseignement, l'étude présente a l'intention d'explorer les relations possibles entre l'utilisation du programme de vie et emotionalization sur des vues ethnocentriques utilisant l'accomplissement de langue étrangère (FLA) le grand nombre. L'équation structurelle modelant (SEM) a été utilisée pour examiner les interactions possibles. Les conclusions ont indiqué que tandis qu'exvolvement, comme une partie d'emotionalization, mène au grand nombre FLA plus haut, la participation montre les résultats opposés. De plus, les résultats ont révélé que l'aspect de langue du programme de vie mène au grand nombre FLA plus haut et l'ethnocentrisme est moins relaté à FLA.

Mots Clés: emotionalization, ethnocentrisme, programme de vie, score d'accomplissement de langue étrangère, langue étrangère, accomplissement de langue 


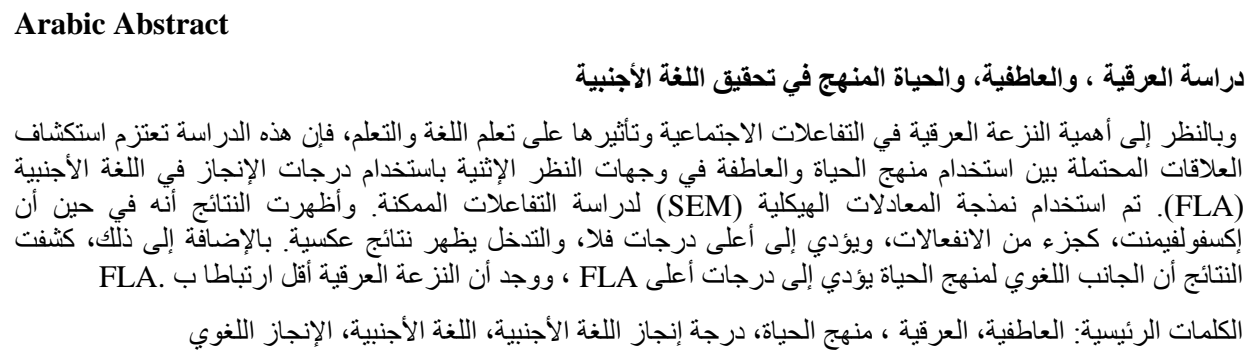

\section{German Abstract \\ Untersuchen Ethnocentrism, Emotionalisierung und Leben Syllabus in Fremdsprache Leistung}

Angesichts der Bedeutung des Ethnozentrismus in sozialen Interaktionen und ihres Einflusses auf das Sprachenlernen und -unterricht beabsichtigt die vorliegende Studie, die möglichen Beziehungen zwischen dem Lebenssuch und der Emotionalisierung auf ethnozentrischen Ansichten mit Hilfe der Fremdsprachenerfolg (FSE) zu erforschen. Structural equation modelling (SEM) wurde genutzt, um die möglichen Wechselwirkungen zu untersuchen. Die Ergebnisse zeigten, dass während der Exvolvement, als Teil der Emotionalisierung, führt zu höheren FSEScores, Beteiligung zeigt die entgegengesetzten Ergebnisse. Darüber hinaus zeigten die Ergebnisse, dass der sprachliche Aspekt des Lebens-Lehrplans zu höheren FSE-Scores führt, und der Ethnozentrismus wurde weniger mit FSE verwandt.

Schlüsselwörter: emotionalisierung, ethnozentrismus, lebenssuch, fremdsprachenerfolg, fremdsprache, sprachkenntnisse

\section{Malaysian Abstract \\ Memeriksa Etnocentrism, Emosionalisasi, dan Silibus Hidup dalam Pencapaian Bahasa Asing}

Memandangkan kepentingan etnosentrisme dalam interaksi sosial dan pengaruhnya terhadap pembelajaran dan pengajaran bahasa, kajian ini bertujuan untuk meneroka hubungan yang mungkin antara menggunakan sukatan pelajaran hidup dan emosionalisasi pada pandangan etnocentric menggunakan skor bahasa pencapaian bahasa (FLA). Pemodelan persamaan struktur (SEM) digunakan untuk meneliti interaksi yang mungkin. Penemuan menunjukkan bahawa sementara kesungguhan, sebagai sebahagian daripada emosionalisasi, membawa kepada skor FLA yang lebih tinggi, penglibatan menunjukkan hasil yang bertentangan. Di samping itu, keputusan menunjukkan bahawa aspek bahasa sukatan pelajaran hidup membawa kepada skor FLA yang lebih tinggi, dan etnosentrisme didapati kurang berkaitan dengan FLA.

Kata Kunci: emosionalisasi, etnosentrisme, sukatan pelajaran hidup, skor pencapaian bahasa asing, bahasa asing, pencapaian bahasa 


\section{Russian Abstract}

Изучение Этноцентризма, Эмоциональности и Жизненного Уровня в Достижении Иностранных Языков

Учитывая важность этноцентризма в социальных взаимодействиях и его влияние на изучение и преподавание языка, настоящее исследование предназначено для изучения возможных взаимосвязей между использованием жизненной программы и эмоциональностью на этноцентрических взглядах с использованием оценки успеваемости на иностранном языке. Моделирование структурных уравнений использовалось для изучения возможных взаимодействий. Выводы показали, что в то время как экспроприация, как часть эмоциональности, приводит к более высоким показателям достижения иностранного языка, вовлечение показывает противоположные результаты. Кроме того, результаты показали, что языковой аспект жизненной программы приводит к более высоким показателям достижения иностранного языка и этноцентризм оказался менее связан с достижением иностранного языка.

Ключевые Слова: эмоциональность, этноцентризм, жизненный уровень, партитура достижения иностранного языка, иностранный язык, языковые достижения 